\title{
AUTOMOBILE CLUB ACTIVITIES: THE PROBLEM FROM THE STANDPOINT OF THE CLUBS
}

\author{
Charles C. Collins*
}

In the United States today there are some eight hundred motor clubs with nearly a million members. All but a very few of these clubs are affliated into one national federation-the American Automobile Association. The A.A.A. motor clubs are civic, non-profit organizations whose purposes are to render service and protection to members and to aid the cause of motoring generally. In carrying out these objectives, many of the clubs perform certain legal or quasi-legal services.

\section{Historical Background}

To appraise the problem of law practice from the automobile club standpoint, it would be well to look into the beginnings of the motor club movement and the conditions that prompted them to institute aid in matters affecting the legal rights of members. In 1902, when the A.A.A. was organized, there were but 23,000 passenger cars in the entire nation; there were practically no improved roads and traffic laws were designed for horse-drawn vehicles. Moreover, the car owners in those days encountered a good deal of hostility, particularly in small rural communities, and this hostility was reflected in laws and regulations that either were unduly oppressive, or were even designed, in some instances, to discourage automobile travel altogether.

In order to better the conditions under which they operated, a number of motoring enthusiasts banded together so they could present a united front in working out their problems. The original call that was sent out to motor clubs thirty-five years ago, inviting them to take part in setting up a national organization, stated that one of the principal purposes in joining together was: "Protection of the legal rights of users of motor vehicles." Wholesale arrests for exceeding five and ten-mile speed limits, for frightening horses, for horn-blowing, and for a score of other petty and technical offenses, together with the appearance of the kangaroo court along the roadside with its fee-splitting officials, at length drove the motor clubs to the necessity of retaining counsel and battling against such injustices.

\section{Types of Service}

While great progress is being made in the standardization of club services, there is still a lack of complete uniformity and this is quite true with regard to legal

- LL.B., I922, Georgetown University. Member of the District of Columbia Bar. Professor of Law, Southeastern University. Contributor to periodicals on legal subjects. 
activities. Generally speaking, however, these so-called legal activities fall into four broad categories:

(I) Sponsorship of legislation deemed to be in the motorists' interest.

(2) Dissemination of information regarding laws affecting motorists.

(3) Providing legal defense for a motorist considered to be the victim of unjust prosecution, particularly where broad public questions are involved.

(4) Attempted settlement of small damage claims without recourse to court action.

As regards the first of these, there has been no question at all about the right of the clubs to engage in such activity. As regards the second, I believe it fair to say that only the most carping critics have raised any question whatsoever as to the right of clubs to distribute information concerning motor laws to members. The other two activities, however, have been the subject of much discussion and will be treated at length in this article.

\section{"Unjust Prosecutions"}

The motor club-and, in using this term, I mean the average motor club giving a typical service-is obliged to appear in defense of members in certain cases in which there is "unjust prosecution," in order that the rights of motorists generally may be protected. The club must necessarily appear in defense of these actions by retaining duly admitted members of the bar. What is meant by the term, "unjust prosecution"? It means simply this: the club will undertake to defend a member when the member is faced with prosecution under a law, ordinance or regulation, which the club believes to be detrimental to the public interest. A few concrete examples will illustrate the point clearly.

The management of a motor club in a large city received a flood of complaints regarding the operation of a "speed trap" in a neighboring village. Upon investigation, the Secretary found that more than one hundred motorists were being arrested and fined every week for violating a local speed ordinance. Each arrested motorist was required to post $\$ 16.00$ collateral and he was led to believe that any attempt to contest the case would result, not in return of any of the money, but rather in an additional fine being imposed. Further investigation disclosed that part of the $\$ 16.00$ was being distributed in the following manner: The prosecuting attorney received $\$ 5.00$ whether there was a trial or not; the mayor, who acted as the trial justice, received $\$ 3.00$; and the two officers making the arrest got $\$ \mathrm{r} .50$ each. With an average of more than one hundred arrests weekly, these busy, fee-splitting enforcement agents were receiving enormous incomes at the expense of motorists.

The motor club referred the complaints to its attorney who found, upon searching the laws of the particular state, that the mayor was entitled to receive only $\$ 1.50$ from the town in the event of an acquittal. The case of an individual motorist was defended and appealed to the higher courts of the state on the ground that the mayor, receiving more in the event that he convicted a defendant than he would receive for his services in the event he acquitted, could not be expected to be above 
partiality. As a result of this action and the attendant publicity, the legislature eventually changed the law under which this type of court operated and such "speed traps" were abolished throughout the state.

In another case, a motorist was arrested for alleged reckless driving. The justice of the peace, before whom the motorist was haled, found him not guilty but nevertheless required him to pay costs amounting to $\$ 2.50$. The motorist immediately complained to his club and the Secretary realized that if this practice were allowed to go on, any and all motorists could be arrested for violating some law of this particular village and found not guilty-but still be required to pay costs. The case was thereupon referred to the club's counsel and the matter was taken to court, with the result that this anti-social practice was discontinued.

In still another instance, a motor club carried to the Supreme Court of the United States a case involving what it believed to be unfair tax exactions by a city government. These are but three instances of the many such cases that are handled by clubs through their attorneys on behalf of individual motorists but for the benefit of all motorists. All of these cases are handled by duly admitted members of the bar and are paid for out of the club treasury.

\section{Claim and Adjustment}

Many of the motor clubs maintain claim and adjustment departments, usually manned by a club employee who is an attorney. However, in the case of some of the clubs the employee handling this service is not an attorney. There are exceptions, of course, but, generally speaking, these departments handle only claims involving less than $\$ 100$, they take no action at all regarding personal injuries and do not go into court. The procedure of the average motor club claim and adjustment department is as follows:

The member presents a written report, giving full details of the accident, together with an estimate of the cost of repairs. A letter is then sent to the other motorist involved, requesting him to advise whether he is willing to pay for the damage done. If he replies, the matter is discussed and an attempt made to settle the claim. If he refers the letter to his insurance carrier, the club employee discusses the matter with the insurance carrier's representative and attempts to reach a settlement.

If there is no response to the letter, the club employee will write another letter or attempt to contact the motorist. If he prefers not to make payment, the club member is advised that he must employ counsel to file suit in the event the member wishes to carry the matter further, since the club has done all that it can under the circumstances. In some of the clubs attorneys will represent the members in court in property damage cases where the amount involved is less than one hundred dollars.

When the accident happens while the club member is traveling or touring outside his home state, the claim is sent to the adjustment department of the club in whose territory the accident happened and the same procedure is followed as that outlined above. Whether collection is made or not, the member pays no charge. 
Reports from motor club claim and adjustment departments in many parts of the country show that collections average less than $\$$ ro.00 per case.

Some of the clubs, in an effort to settle small disputes arising from automobile accidents, hold arbitrations in cases where the parties involved agree to this procedure. These arbitrations are presided over by club members; the involved motorists and their witnesses appear and testify, and a decision is rendered by the arbitrators. In this manner many small claims are kept out of courts, already over-congested. These arbitrations are usually limited to cases where less than \$roo property damage is involved and never deal with personal injury cases.

\section{The British Clubs}

Before proceeding to a discussion of the merits of these activities, it might be of interest to note what the motor clubs of Great Britain do in the way of legal service for members. The British practices are cited because our motor clubs are closely comparable with theirs; our laws are based on their laws, and our ethics to a large extent are taken from, or grounded upon their ethics.

The wide extent of the legal services provided by the English clubs is succinctly set forth in the following extract from the "Handbook" of the British Automobile Association:

\section{LEGAL DEPARTMENT. FREE LEGAL DEFENSE}

Free Legal Defense (by the Association's solicitors) is afforded (a) to every car member and owner-driver, (b) to every member who is the owner-driver of a cyclecar, and (c) to every motorcycle member in any proceedings under the Motor Car Act and Roads Act in Courts of Summary Jurisdiction in the United Kingdom.

A few of the offences covered by the Free Legal Defense Scheme are:

Driving recklessly or to the public danger.

ExceEding the speed limit.

FAILURE properly to illuminate identification plates.

Allowing identification marks to be obscured.

Non-CoMPLIANCE with the regulations relating to registration, licensing, etc. etc.

Experience has shown that despite the exercise of every caution, the most careful motorist is liable to be charged with having committed an infringement of the law. This is especially so in the case of small technical points.

At one time many cases were allowed to go undefended in view of the trouble and expense involved in retaining the services of a solicitor, and this, of course, was prejudicial not only to the interest of the individual but to those of the motoring community. For that reason, and to render members the maximum of assistance, the Free Legal Defense Scheme was inaugurated. The scheme has been in force since July $x 909$, and the continued high percentage of successful defenses is a testimony to the value of this benefit. All that the member has to do is to place the conduct of any summons of the nature referred to in the hands of the Association, when the Association's solicitors go carefully into the evidence and defend the case.

... The Committee, however, reserves the right to withhold the benefit of Free Legal Defense in any case where in their view the circumstances are such as to render this course desirable. 
.. The Association has extended its Free Legal Defense Scheme to include Free Legal Assistance by the Association's solicitors in approved civil cases arising out of the use or ownership of privately owned motorcars or motorcycles.

This extension really aims at giving the greatest possible assistance in claims and disputes not ordinarily covered by insurance, and to protect members against the too-frequent attempts of the unscrupulous to deprive the motorist of his rights.

\section{FREE LEGAL ADVICE}

Every member of the Association is entitled to the advice of the Legal Department on any matter directly arising out of the use and ownership of motorcars or motorcycles.

Disputes over buying and selling of cars, liability for accidents on the road, claims for damage in transit, responsibility of garage proprietors, queries on the Motor Car Act, and the various regulations governing registration, licensing, storage of petrol, etc., are only a few of the matters in which the Association is able to help members in any advisory capacity. It is frequently possible to assist in securing a satisfactory settlement of cases and avoid the expense and inconvenience of litigation.

The Royal Automobile Club renders legal services similar to those of the British Automobile Association. As a result of the affiliation of the A.A.A. with the British clubs, a member from the United States traveling abroad can get all these services which he can not get at home.

It no doubt will be a surprise to many in America that the British legal profession, which carefully guards the prerogatives of its members, offers no objections to this broad and sweeping type of legal service for motor club members. Questioned on this point, Messrs. Amery-Parkes \& Co., of London, general counsel for the British Automobile Association, made the following comment:

"We have never heard any objection being taken to an Advocate being retained for the Defense of a motorist, or indeed, even of a criminal, by a third party. Still less can we conceive it possible that any objection would be taken to an Advocate briefed by an organization of which the Defendant was an Association member in circumstances where the member paid the subscription to the organization, one of the terms of which was that he would be entitled to free legal defense."

In brief, the motor clubs of Great Britain provide legal services far beyond the scope of those provided by clubs in the United States, with the full sanction of the members of the legal profession.

\section{The Motor Clubs' Viewpoint}

The services performed by the motor clubs in protecting the legal rights of their members are provided because the members have a right to, and demand, such services, and because such services are not obtainable except through a motor club.

It is not now, nor was it ever, the intention of the automobile clubs to engage in the legal business or to take away from the practicing lawyer any business which he cared to handle or which he might profitably handle. As a matter of fact, the reverse is true. The activities of the clubs in connection with cases involving unjust 
prosecutions have in many instances resulted in providing practicing lawyers with cases that otherwise would not have been litigated.

As already stated, there is no question at all as to the right of the motor clubs to sponsor legislation in the motorists' interest. As a result of working through their organizations, the motorists have brought about almost nation-wide adoption of financial responsibility legislation; they have secured at least a measure of uniformity in traffic regulations of the various states; and they have defeated, time and again, proposed laws that would have been unduly restrictive. Individually, the motorists could have done nothing along these lines; collectively, they have accomplished much.

With regard to dissemination of information on laws affecting motorists, it is obvious that the average practicing lawyer does not have in his library all of the motor vehicle laws of the various states; he does not have at his fingertips the details of such matters as guest suit laws, reciprocity regulations, non-resident service of process laws, and the other complexities that have resulted from regulation by federal, state and local governments of motor transport; and he can scarcely hope to keep abreast of the thousand or more measures passed by the legislatures at recurring sessions affecting motor vehicle operation. Dissemination of this important information to members and non-members alike is a regular service of motor clubs and is possible only because of their organized effort.

Turning to the matter of unjust prosecution, we believe that motorists as a class have an inalienable right to protection against injustices. As individuals, they have no way of obtaining relief. The amount of money involved in any one individual case is usually small, the grievance not severe-but the interests of motorists as a class may be very adversely affected. The only recourse, then, is for the club, acting on behalf of all motorists, to champion the cause of one individual, secure counsel for him and pay the expenses of the trial from the club treasury. In the cases mentioned above, in which clubs defended unjust prosecutions, the actual amounts of money involved were so small as to be practically negligible-in one case, $\$ 16.00$, and in another, $\$ 2.50$. Clearly, no individual motorist can afford to thresh out a legal problem before the courts for a matter of sixteen dollars or so, but motorists as a whole can afford to carry matters affecting their common interests to the courts and, moreover, demand the right to do so. The sole way in which this is possible is by cooperative action through their motor clubs.

If our American legal set-up provided some means whereby test cases involving wide public interest could be settled in the courts without placing a heavy burden of expense upon a single individual, there would be little necessity for the clubs to handle these unjust prosecution cases. As the situation is now, however, this phase of the motor clubs' activities must be continued or motorists as a class will be left without recourse to the courts in matters affecting their broad legal interests.

The claim and adjustment service of the clubs, on the other hand, provides aids 
for the motorist individually rather than for motorists as a group. As pointed out earlier in the article, the operations of the claim and adjustment departments, generally speaking, involve only damage claims of less than \$10o. They do not deal with personal injury cases and the average recovery is less than \$ro.oo per case. There are two primary reasons why the clubs feel they are not only justified, but obligated to render this personal service to members: first, the amounts involved are so small as to make it unprofitable for the motorist to employ his own attorney to handle the case; second, they believe this activity to be merely an attempt to reach an amicable agreement in small property damage cases.

It seems hardly necessary to labor the point that cases which result in average collections of less than \$ro.00 are not within the scope of the practicing attorney. In the majority of the damage claims handled by clubs, the amount claimed would hardly equal the attorney's fee and the amount that can reasonably be expected to be recovered would be substantially smaller than the attorney's fee.

Following is a schedule of attorneys' fees representing the average of the minimum fees suggested by the lawyers of Missouri in response to a questionnaire sent out by a committee of the bar association of that state $\mathbf{1}^{\mathbf{1}}$

Cities over 100,000

Trials in J. P. Courts............................ \$25.00

Trials in Circuit Court............................. \$125.00 to $\$ 150.00$ Appearing as Local Counsel, Circuit Court................ \$75.00

Where per diem charge is made for:

r. Appearance in Circuit Court.................... \$50.00 to $\$ 75.00$

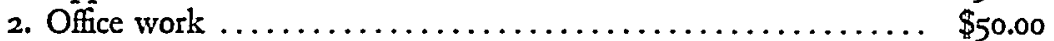

Drawing Simple Contract............................ \$25.00

(Other fees reported for abstracts, drawing wills, etc., are not enumerated here, as they can have no possible application to this question).

Cities of 50,000 to 100,000

Trials in $\mathrm{J} . \mathrm{P}$. Courts............................. \$25.00

Trials in Circuit Court........................... \$50.00

Appearing as Local Counsel, Circuit Court................ \$50.00

Per diem charge:

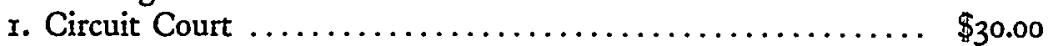

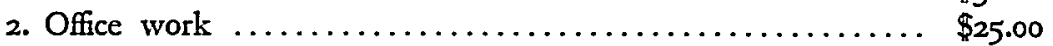

Drawing Simple Contract.......................... \$10.00

Cities Having Less than 50,000

Trials in J. P. Courts............................... \$10.00

Trials in Circuit Court............................. \$50.00

Appearing as Local Counsel, Circuit Court..................\$25.00

Per diem charge:

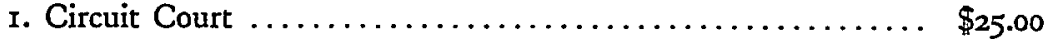

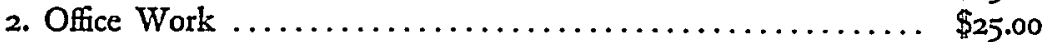

Drawing Simple Contract........................... \$10.00

${ }^{1}$ (1934) 5 Mo. B. J. 225. 
While set schedules are the exception rather than the rule, it is true that the Missouri schedule is indicative of the fees the average claimant may expect to pay. It is obvious that he is not going to employ counsel and take to court a case that gives promise of returning less than half the money he will pay his attorney. His only alternatives are to suffer the loss or depend upon his club to reach an agreement on his behalf.

Anything that the motor clubs can do through their claim and adjustment departments to settle the differences arising from the daily operation of nearly $30,000,000$ passenger cars redounds to the benefit not only of the motorist but also of the already over-congested courts, and does not take business away from lawyers because it is business that does not involve enough money to warrant counsel to devote time necessary to handle the cases.

To recapitulate, then, the motor clubs are providing services to motorists which they demand as their right but which are not available to them except through their motor clubs. If these services were to be discontinued tomorrow by every motor club, the legal profession would gain nothing; rather, the effect would be injurious for many attorneys would lose an important and wholly legitimate source of revenue and the cases involving interests of motorists as a whole, and which are handled by duly admitted members of the bar, would not be litigated at all.

It goes almost without saying that the legal profession is strongly represented throughout the many ramifications of motor club organization. Not only are thousands of lawyers among the oldest and most valued members; not only are attorneys regularly employed by the clubs; but they also hold high positions as officers and directors of the clubs; they hold important posts on the committees and governing bodies of the national organization; and their counsel and advice is enlisted in preparing model legislation and shaping the policies of the organization in its battle for the motorists' welfare. Many of these lawyer members of A.A.A. clubs use the service themselves and very frequently send their clients to the clubs. Scores of prominent directors of A.A.A. clubs are regularly pleading cases before the highest courts of the states and before the Supreme Court of the United States. Is it conceivable that this type of lawyer would condone anything that he believed to be not in the public interest or detrimental to his own profession?

The automobile clubs are not taking away from lawyers any business that is profitable; they have no wish to enter into the practice of law; and desire merely to continue their present services in protecting the motoring public. In the final analysis, it may be said that the determination of the extent to which the motor clubs can and should afford this protection is a matter for the public itself to determine.

The motor clubs feel that in thus protecting the motorist, they are acting properly within their own sphere and providing the motorist with services he could not get elsewhere. Organized effort for the promotion of common interests and welfare is an integral part of the American system and, lest we forget, it is becoming more so every day. 